\title{
THE INFLUENCE OF ICE-CRYSTAL SIZE ON GREEP
}

\author{
By RoBert W. BAKeR \\ (Department of Plant and Earth Sciences, University of Wisconsin-River Falls, River Falls, \\ Wisconsin 54022, U.S.A.)
}

\begin{abstract}
Uniaxial compression tests were conducted on polycrystalline-ice samples with random $c$-axis orientation and steady-state creep rates were determined. Experiments were conducted on both inclusionbearing and inclusion-free ice and were run at constant stress and constant temperature. During freezing, the presence of inclusions in low concentrations inhibits crystal growth; variations in the volume-fraction of inclusions thus result in variations in ice-crystal size. The creep rate of polycrystalline ice at high temperatures and moderate stresses is extremely sensitive to variations in ice-crystal size. Due to an apparent inversion between dislocation-controlled creep and diffusion-controlled creep, the optimum grain size for creep resistance is about $1.0 \mathrm{~mm}$. Increasing or decreasing the average crystal size from this critical value results in an increase in secondary-creep rate.
\end{abstract}

RÉsumé. L'influence de la taille des cristaux de glace sur le glissement. Des tests de compression uniaxiale ont été entrepris sur des échantillons de glace polycristalline avec une orientation au hasard des axes-c et la vitesse de glissement en régime permanent a été déterminée. Les expériences ont été conduites sur des glaces chargées en inclusions et sur des glaces sans inclusions à contraintes et températures constantes. Au cours du gel, la présence de faibles concentrations d'inclusions empêche la croissance des cristaux; les variations dans le pourcentage en volume d'inclusions provoque donc des variations dans la dimension des cristaux de glace. La vitesse de glissement de la glace polycristalline à haute température et sous des contraintes modérées est extrêmement sensible aux variations des dimensions des cristaux. En raison d'une apparente inversion entre le glissement contrôlé par les dislocations et celui contrôlé par la diffusion, la dimension optimum des grains pour une meilleure résistance au glissement est d'environ $1,0 \mathrm{~mm}$. L'augmentation ou la diminution de la dimension moyenne des cristaux à partir de cette valeur critique provoque un accroissement dans la vitesse du glissement secondaire.

Zusammenfassung. Der Einfluss der Eiskristallgrösse auf das Kriechen. Polykristalline Eisproben mit Zufallsorientierung der $c$-Achsen wurden unter einachsigem Druck getestet, wobei die stationären Kriechgeschwindigkeit bestimmt wurden. Die Versuche erstreckten sich sowohl auf Eis mit Einschlüssen wie auf einschlussfreies Eis unter konstanter Spannung und Temperatur. Während des Gefrierens behindert das Vorhandensein von Verunreinigungen in geringer Konzentration das Wachsen der Kristalle; Schwankungen im Volumenanteil der Verunreinigungen führen so zu Schwankungen in der Eiskristallgrösse. Die Kriechgeschwindigkeit polykristallinen Eises bei hohen Temperaturen und mässigen Spannungen ist äusserst empfindlich gegen Schwankungen in der Kristallgrösse. Infolge einer offensichtlichen Inversion zwischen versetzungsbestimmtem und diffusionsbestimmtem Kriechen liegt die günstigste Korngrösse der Widerstandsfähigkeit gegen Kriechen bei , o mm. Weicht die mittlere Kristallgrösse von diesem kritischen Wert nach oben oder unten ab, so steigt die sekundäre Kriechgeschwindigkeit an.

\section{INTRODUGTION}

Most theories for the flow of ice masses assume an isotropic structure throughout. This is clearly not the case as variations in crystal size are common in glaciers.

Prior to the present study, no detailed investigation of the variation of creep rate with ice-crystal size had been conducted. Gold's (1958) tests on columnar-grained ice showed a dependence of Young's modulus $E$ on grain-size - the smaller the average crystal diameter, the smaller the value of $E$ at constant temperature. Butkovitch and Landauer (I958, I96o) found that for randomly oriented polycrystalline samples, in general, the samples with large crystals tended to deform more rapidly than those with smaller crystals. Their studies at low stresses (Butkovich and Landauer, I960) showed that the deformation rate of ice with an average crystal size of 10 to $20 \mathrm{~mm}$ was about four to five times as great as that of ice with an average grain size of about $3 \mathrm{~mm}$. Bromer and Kingery ( 1968 ) found that for columnargrained polycrystalline samples with average crystal size ranging from about $2 \mathrm{~mm}$ to $5 \mathrm{~mm}$, the viscosity was proportional to the grain-size squared. The only other work dealing with crystal size was conducted by Muguruma (1969) who also tested columnar-grained ice. In tests on samples with average grain sizes greater than $2 \mathrm{~mm}$, he found that the upper-yield stress $\sigma_{\max }$ is related to grain size by the equation

$$
\begin{gathered}
\sigma_{\max }= \\
\sigma_{0}+k d^{-\frac{1}{2}}, \\
4^{85}
\end{gathered}
$$


where $\sigma_{0}$ and $k$ are constants and $d$ is the average grain diameter. This equation is a form of the Hall-Petch relationship (Hall, I95I ; Petch, I 953) between yield stress and grain size in materials such as ice that begin plastic deformation with a low density of mobile dislocations (Weertman, 1973, p. 323).

\section{EXPERIMENTAL PROGEDURE}

Polycrystalline samples of clean ice were prepared by packing powdered ice, made from frozen de-ionized distilled water, into cylindrical moulds which were $19.5 \mathrm{~mm}$ in diameter and roo $\mathrm{mm}$ long. The moulds were de-aerated, void spaces filled by admitting air-free distilled water at $0^{\circ} \mathrm{C}$, and then frozen solidly in a cold laboratory kept at about $-10^{\circ} \mathrm{C}$. Samples thus prepared were virtually free of bubbles. Ultra-fine-grained samples were prepared similarly except that moulds were immersed in a bath of dry ice (solid $\mathrm{CO}_{2}$ ) and methanol and frozen essentially instantaneously. A $30 \mathrm{~mm}$ section was cut from the central portion of the sample, and the ends of this section were carefully faced perpendicular to the long axis. Sample diameter was measured at twelve points using a micrometer which could be read to $\pm \mathrm{I} \mu \mathrm{m}$. Sample length was measured in initial tests with a steel tape to the nearest $0.2 \mathrm{~mm}$ and in later tests with a micrometer to $\pm \mathrm{r} \mu \mathrm{m}$.

Samples containing dispersed-solid inclusions were prepared and measured in similar fashion except that the mould was filled with a porous mixture of well-sorted Ottawa sand and powdered ice, and the $30 \mathrm{~mm}$ section was cut from the portion of the sample having the most uniform sand distribution. After completion of the compression test, samples were cut in half and inclusion concentrations in the two halves were determined by melting the ice and weighing the sand residue. By assuming a density of $9 \times 10^{-4} \mathrm{~g} \mathrm{~mm}^{-3}\left(0.9 \mathrm{Mg} \mathrm{m}^{-3}\right)$ for ice and $2.7 \times \mathrm{IO}^{-3} \mathrm{~g} \mathrm{~mm}^{-3}\left(2.7 \mathrm{Mg} \mathrm{m}^{-3}\right)$ for sand, concentrations were reduced to per cent sand by volume. Inclusion concentrations in the two halves of the same sample generally varied by less than $5 \%$ of the amount present.

A constant uniaxial load was applied parallel to the long axis of each sample. Tests were run in a cold laboratory, generally kept at about $-10^{\circ} \mathrm{C}$, using the ice-compression apparatus described by Hooke and others (1972) in their deformation experiments. To prevent sublimation and control temperature, ice samples were immersed in a bath of kerosene. The bath was stirred with a miniature gear pump and temperature was controlled with a Lauda-Brinkman K-4/R circulator. Bath temperature generally fluctuated less than o. I deg during a run.

Deformation measurements were made using a Hewlett Packard 7 DCDT-500 displacement transducer connected to a strip chart recorder. This system was calibrated with a drum micrometer and Schmitt trigger using the method described by Hooke and others (1972, p. 327 ). A displacement of $1 \mathrm{~mm}$ on the chart recorder corresponded to a compression of the sample of $3.1 \pm 0.2 \mu \mathrm{m}$.

Throughout each test, the temperatures of the bath and cold laboratory were read at oneto three-hour intervals during the day. There was generally a 6 to $7 \mathrm{~h}$ gap in the readings between about midnight and 7 a.m. Discrete measurements, generally at 20 to 40 points, were made at regular intervals of about $10 \mathrm{~mm}$ on the curves of total strain versus time from the chart recorder. The slope of the curve in the region of secondary creep was determined from these measurements using a least-squares method. To allow for primary creep, the time interval used for this calculation generally started more than $40 \mathrm{~h}$ after initial application of stress. The curves of total strain versus time were not always smooth, but often contained numerous $\mathrm{I}$ to $2 \mathrm{~mm}$ steps representing $3 . \mathrm{I} \times \mathrm{IO}^{-3}$ to $6.2 \times \mathrm{IO}^{-3} \mathrm{~mm}$ of strain. Such discrete measurements at regular intervals provide both a measure of the slope of the curve and the uncertainty in this slope, as points falling immediately before or after a step may either underestimate or perhaps overestimate the total strain at that time. It is not known whether the steps are due to sticking in the seemingly well-lubricated system or actual jerky displacements 
TABle I. Summary of EXPERIMENTAL RESUlts on INCLUSION-FreE ICE

\begin{tabular}{|c|c|c|c|c|c|c|c|c|c|c|}
\hline \multirow[b]{2}{*}{ Sample } & \multirow[b]{2}{*}{$\begin{array}{l}\text { Initial } \\
\text { length } \\
\mathrm{mm}\end{array}$} & \multirow{2}{*}{\multicolumn{2}{|c|}{$\begin{array}{c}\text { Applied } \\
\text { stress }\end{array}$}} & \multicolumn{2}{|c|}{$\begin{array}{l}\text { Time interval over } \\
\text { which creep rate } \\
\text { was determined } \\
\end{array}$} & \multirow{2}{*}{\multicolumn{2}{|c|}{$\begin{array}{l}\text { Normalized } \\
\text { strain-rate }\end{array}$}} & \multirow{2}{*}{$\begin{array}{l}\text { Average } \\
\text { grain } \\
\text { size } \\
\mathrm{mm}\end{array}$} & \multicolumn{2}{|c|}{$\begin{array}{l}\text { Temperature } \\
\text { during } \\
\text { measurement } \\
\text { interval }\end{array}$} \\
\hline & & & & $\begin{array}{c}\text { Start, } \\
\text { time from } \\
\text { beginning } \\
\text { of run } \\
\mathrm{h}\end{array}$ & $\begin{array}{c}\text { Dura- } \\
\text { tion } \\
\mathrm{h}\end{array}$ & & & & $\underset{{ }^{\circ} \mathrm{C}}{\text { Mean }}$ & $\begin{array}{c}\text { Range } \\
\text { deg }\end{array}$ \\
\hline Ia & 30.7 & 0.56 & $(5.6)$ & 34 & 33 & I. 30 & $(0.4 \mathrm{I})$ & I. 13 & $-7 \cdot 5$ & 0.00 \\
\hline $\mathrm{Ib}$ & 25.9 & $0.4^{8}$ & $(4.8)$ & 246 & 16 & $7 \cdot 5^{8}$ & (2.39) & 1.95 & -7.6 & 0.00 \\
\hline 2 & 33.8 & 0.57 & $(5.7)$ & 43 & 19 & 5.01 & (1. $\left.5^{8}\right)$ & 1. 37 & -7.6 & 0.01 \\
\hline 3 & 31.4 & $0.5^{6}$ & $(5.6)$ & 80 & 10 & 10.72 & $\left(3.3^{8}\right)$ & г. 80 & -7.6 & 0.08 \\
\hline 4 & 33.8 & 0.57 & $(5 \cdot 7)$ & 75 & 43 & 2. 13 & $(0.67)$ & I. 17 & -7.6 & o.ro \\
\hline 5 & 33.5 & $0.5^{6}$ & $(5.6)$ & 46 & 33 & 2.89 & $(0.9 \mathrm{I})$ & I. 19 & -7.7 & 0.18 \\
\hline 6 & $3^{2.8}$ & 0.55 & $(5 \cdot 5)$ & 40 & 14 & 7.10 & $(2.24)$ & 2.04 & -7.7 & 0.05 \\
\hline $7 \mathrm{a}$ & $29 \cdot 9$ & 0.57 & $(5 \cdot 7)$ & 57 & 25 & 2.44 & $(0.77)$ & 1.36 & -7.7 & 0.01 \\
\hline $7 \mathrm{~b}$ & 28.4 & 0.55 & $(5 \cdot 5)$ & 130 & 13 & 7.20 & $(2.27)$ & 1. $9^{2}$ & -7.1 & 0.02 \\
\hline 8 & 36.0 & $0.5^{8}$ & $(5.8)$ & 45 & 28 & 2.73 & $(0.86)$ & I. 15 & -7.1 & 0.09 \\
\hline $9^{a}$ & 32.8 & $0.5^{6}$ & $(5.6)$ & 43 & 14 & 5.68 & (1.79) & 0.62 & $-7 \cdot 1$ & 0.09 \\
\hline $9 b$ & 24.0 & 0.45 & $(4 \cdot 5)$ & 174 & 15 & $7 \cdot 5^{8}$ & $(2.39)$ & 1.86 & $-7 \cdot 1$ & 0.05 \\
\hline IO & $29 \cdot 3$ & $0.5^{8}$ & $(5.8)$ & 449 & I I & 2.13 & $(0.67)$ & 1.06 & - I0.9 & 0.07 \\
\hline I I a & 28.6 & 0.55 & $(5 \cdot 5)$ & 45 & 23 & 5.90 & (1.86) & I. 45 & -9.8 & o.19 \\
\hline I I b & 27.7 & 0.54 & $(5 \cdot 4)$ & 314 & 17 & 9.70 & $(3.06)$ & 2.11 & -6.0 & 0.09 \\
\hline 12 & 32.8 & $0.5^{6}$ & $(5.6)$ & 46 & 30 & 3.62 & (1.14) & 1. 65 & - IO.I & 0.13 \\
\hline I $3 a$ & 32.6 & 0.57 & $(5 \cdot 7)$ & $5^{2}$ & 29 & 3.62 & (1.14) & 1.22 & -8.6 & 0.04 \\
\hline $13 \mathrm{~b}$ & 31.6 & 0.55 & $(5 \cdot 5)$ & 401 & 10 & I2. I I & $(3.82)$ & 2.14 & -8.8 & 0.10 \\
\hline 14 & 30.4 & $0.5^{6}$ & $(5.6)$ & 48 & I I & $13.5^{I}$ & $(4.26)$ & 0.65 & $-9 \cdot 7$ & o. I 8 \\
\hline 15 & 29.9 & 0.55 & $(5 \cdot 5)$ & 43 & 14 & $9 \cdot 35$ & $(2.95)$ & 0.69 & -10.0 & 0.10 \\
\hline $1 \overline{6}$ & $29 . \overline{6}$ & $0.5^{6}$ & $(5.6)$ & 42 & 16 & 8.34 & (2.63) & 0.74 & -10.0 & 0.05 \\
\hline 17 & 32.7 & $0.5^{6}$ & $(5.6)$ & 44 & 14 & 8.15 & $(2.57)$ & 0.77 & -10.0 & 0.00 \\
\hline 18 & 30.9 & 0.55 & $(5 \cdot 5)$ & $4^{I}$ & 12 & 12.49 & $(3.94)$ & 0.68 & -9.1 & 0.00 \\
\hline I9 & 33.9 & 0.57 & $(5.7)$ & 44 & 21 & $4 \cdot 3^{8}$ & $\left(1 \cdot 3^{8}\right)$ & 1. $5^{8}$ & -7.6 & 0.00 \\
\hline 20 & 33.1 & $0.5^{6}$ & $(5.6)$ & $6 \mathrm{I}$ & II & 11.67 & $(3.68)$ & 2.05 & -7.6 & 0.02 \\
\hline
\end{tabular}

TABLE II. SUmmary of EXPERIMENTAL RESUlts on INGlusion-BEARING IGE

\begin{tabular}{|c|c|c|c|c|c|c|c|c|c|c|c|}
\hline \multirow[b]{2}{*}{ Sample } & \multirow[b]{2}{*}{$\begin{array}{l}\text { Initial } \\
\text { length } \\
\mathrm{mm}\end{array}$} & \multirow{2}{*}{\multicolumn{2}{|c|}{$\begin{array}{c}\text { Applied } \\
\text { stress }\end{array}$}} & \multirow{2}{*}{\multicolumn{2}{|c|}{$\begin{array}{l}\text { Time interval over } \\
\text { which creep rate } \\
\text { was determined } \\
\text { Start, } \\
\text { time from } \\
\text { beginning Dura- } \\
\text { of run tion } \\
\mathrm{h} \quad \mathrm{h}\end{array}$}} & \multirow{2}{*}{\multicolumn{2}{|c|}{$\begin{array}{l}\text { Normalized } \\
\text { strain-rate }\end{array}$}} & \multirow{2}{*}{$\begin{array}{l}\text { Average } \\
\text { grain } \\
\text { size } \\
\mathrm{mm}\end{array}$} & \multirow{2}{*}{$\begin{array}{l}\text { Volume } \\
\text { fraction } \\
\text { sand }\end{array}$} & \multicolumn{2}{|c|}{$\begin{array}{l}\text { Temperature } \\
\quad \text { during } \\
\text { measurement } \\
\text { interval }\end{array}$} \\
\hline & & & & & & & & & & $\underset{{ }^{\circ} \mathrm{C}}{\text { Mean }}$ & $\begin{array}{c}\text { Range } \\
\text { deg }\end{array}$ \\
\hline I & 30.0 & 0.56 & $(5.6)$ & 47 & 12 & $5 \cdot 30$ & $(\mathrm{r} .67)$ & 0.76 & 0.022 & -10.7 & 0.08 \\
\hline 2 & $29 \cdot I$ & 0.56 & $(5.6)$ & $4^{8}$ & I9 & 8.09 & $(2.55)$ & 0.77 & 0.049 & -9.9 & O. I I \\
\hline $3^{a}$ & $3 \mathrm{I} \cdot 7$ & 0.55 & $(5.5)$ & 49 & 15 & 5.07 & $(1.60)$ & 0.79 & 0.013 & -10.6 & 0.09 \\
\hline $3 \mathrm{~b}$ & 31.0 & 0.54 & $(5.4)$ & 344 & I I & $9 \cdot 13$ & $(2.88)$ & 1.91 & 0.013 & -6.7 & 0.06 \\
\hline 4 & 33.8 & 0.56 & $(5.6)$ & 47 & 12 & 9.10 & $(2.87)$ & 0.63 & 0.066 & -10.7 & 0.00 \\
\hline 5 & $3 \mathrm{I} \cdot \mathrm{I}$ & 0.54 & $(5.4)$ & 67 & 16 & I I. 38 & (3.59) & $0.5^{6}$ & 0.065 & -10.0 & 0.05 \\
\hline $6 a$ & 26.5 & 0.55 & $(5 \cdot 5)$ & 53 & 27 & 6.75 & (2.13) & 0.73 & 0.012 & -10.1 & 0.05 \\
\hline $6 \mathrm{~b}$ & 26.4 & 0.55 & $(5 \cdot 5)$ & 127 & 36 & 5.84 & (1.84) & 0.87 & 0.012 & -10.0 & 0.04 \\
\hline 7 & 33.1 & 0.55 & $(5 \cdot 5)$ & 36 & 22 & 7.07 & (2.23) & 0.82 & 0.006 & -10.1 & 0.20 \\
\hline $8 a$ & $29 \cdot 3$ & $0.5^{6}$ & $(5.6)$ & 37 & 30 & 4.60 & (1.45) & $0.8 \mathrm{I}$ & 0.003 & -10.0 & 0.05 \\
\hline $8 \mathrm{~b}$ & 29.1 & 0.55 & $(5 \cdot 5)$ & I 6 & 43 & 4.00 & $(1.26)$ & $0.9^{2}$ & 0.003 & -10.1 & 0.03 \\
\hline 9 & 30.8 & 0.55 & $(5 \cdot 5)$ & $4^{8}$ & 34 & 5.04 & $(\mathbf{1} .59)$ & 0.84 & 0.002 & -10.1 & 0.15 \\
\hline Io & $29 \cdot 4$ & 0.55 & $(5 \cdot 5)$ & 38 & 26 & 6.66 & $(2.10)$ & 1.53 & 0.001 & -10.0 & 0.00 \\
\hline I I & 27.1 & 0.55 & $(5 \cdot 5)$ & 54 & 27 & $7 \cdot 45$ & $(2.35)$ & 0.77 & 0.004 & -11.0 & 0.10 \\
\hline I $2 \mathrm{a}$ & 29.5 & 0.55 & $(5 \cdot 5)$ & 48 & 22 & 7.93 & $(2.50)$ & 1. 76 & 0.039 & -10.0 & 0.00 \\
\hline $12 \mathrm{~b}$ & 28.8 & 0.54 & $(5.4)$ & 223 & I 6 & 10.53 & $(3 \cdot 32)$ & 1.89 & 0.039 & - II.O & 0.10 \\
\hline I3 & 28.3 & 0.55 & $(5 \cdot 5)$ & $5^{\circ}$ & 25 & 8.12 & $(2.56)$ & I.79 & 0.001 & -10.0 & 0.00 \\
\hline $14 a$ & 32.5 & 0.56 & $(5.6)$ & $4^{2}$ & 17 & $5 \cdot 45$ & $(1.72)$ & 0.84 & 0.007 & - го 0.6 & 0.00 \\
\hline $14 \mathrm{~b}$ & 32.1 & $0.5^{6}$ & $(5.6)$ & I 34 & I 8 & 5.84 & (1.84) & 1.75 & 0.007 & -10.2 & 0.00 \\
\hline
\end{tabular}


in the samples. Parameswaran (1975), however, observed similar strain steps in ice and attributed them to a stress-induced ordered region moving with dislocations through the ice lattice.

In the present study, the total strain ranged from 5 to $15 \%$. For tests in which the total strain was less than $10 \%$, some primary creep may be included in the measured strain-rate (Weertman, 1969). To test for this, the least-squares procedure described by Hooke and others (1972, p. 329) was used to fit Andrade's Law to the curve of total strain versus time over the time interval defined previously. In general, the secondary-creep rate determined by this method differed from the slope of a straight line by less than $3.15 \times 10^{-9} \mathrm{~s}^{-1}(0.0 \mathrm{I}$ year $\left.^{-1}\right)$. Hence, it is assumed that the slope of a straight line through the data provides an accurate measure of the secondary-creep rate. Stress differences between runs ranged from 0.45 to $0.5^{8} \mathrm{MN} \mathrm{m}^{-2}$ ( 4.5 to $5.8 \mathrm{bar}$ ) while temperature differences ranged from -6.0 deg to - I I.o deg (Tables I and II). Thus to facilitate comparison, creep rates were normalized to a stress of $0.56 \mathrm{MN} \mathrm{m}^{-2}(5.6 \mathrm{bar})$ and a temperature of $-9 . \mathrm{I}^{\circ} \mathrm{C}$ using the relationship described by Hooke and others (1972, p. 329) which is based on Glen's flow law and the Arrhenius equation (Glen, i 955 ). The effective activation energy at $-9^{\circ} \mathrm{C}$ used in the normalization procedure was determined graphically from figure 3 of Mellor and Testa (1969) and is about $87.6 \mathrm{~kJ} \mathrm{~mol}^{-1}$ (2 $\left.\mathrm{I} \mathrm{kcal} \mathrm{mol}^{-1}\right)$.

Thin sections were cut from samples both before and after testing. These sections were photographed and average crystal size was determined from enlarged photographs using the maximum chord-intercept method of Krumbein (1935). This technique was recently shown to be highly efficient in approximating the true sieve-diameter distribution from thin sections (Kellerhals and others, I975). Since crystal sizes and shapes appeared to be uniform (Fig. I), it is assumed that this method provides an accurate measure of the average grain size. From a given thin-section photograph, the measured average crystal size was reproducible to within $\pm 0.05 \mathrm{~mm}$. The average crystal size from thin sections cut from both ends of samples generally varied by less than $0 . \mathrm{I} \pm 0.05 \mathrm{~mm}$, a grain size difference of less than $10 \%$. Sections cut from each sample both before and after testing showed no measurable changes in grain size during testing. For a more detailed description of the experimental procedure, the reader is referred to Baker (unpublished).

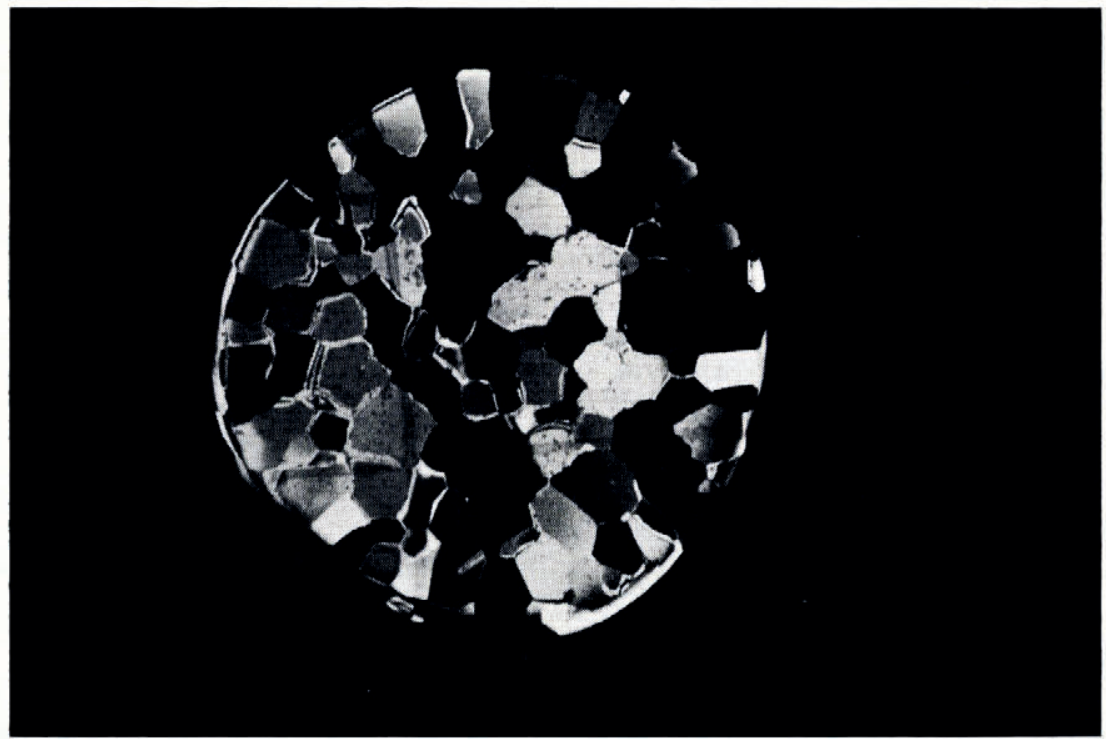

Fig. I. Thin-section photograph of a typical compression sample. Diameter of sample is $1.90 \mathrm{~cm}$. 


\section{Results}

Results of the tests on inclusion-free ice and inclusion-bearing ice are presented in Tables I and II, respectively. Data from these tables were used to make the double logarithm plot of normalized secondary-creep rate versus average grain diameter shown in Figure 2.

From Figure 2, it can be seen that secondary-creep rate is sensitive to variations in icecrystal size. Increasing or decreasing the average grain size from about $1.0 \mathrm{~mm}$ results in a marked increase in secondary-creep rate. In fact, a doubling or halving of the average crystal size from about $1.0 \mathrm{~mm}$ results in approximately a factor of four increase in creep rate. Based on the strong similarity of the data for both clean and inclusion-bearing ice, it appears that the presence of inclusions in low concentrations does not affect the relationships in Figure 2.

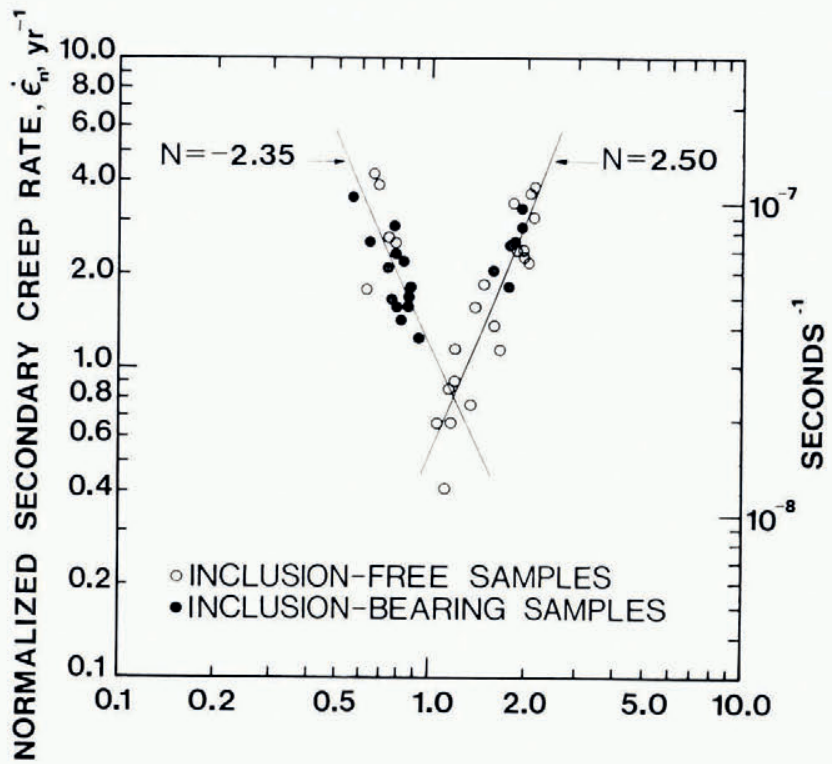

AVERAGE GRAIN DIAMETER,d, mm

Fig. 2. Normalized secondary-creep rate versus average grain diameter for both inclusion-free and inclusion-bearing samples. Lines with slopes $\mathcal{N}$ were fitted to the data using least-squares methods. Points located near the intersection of the two lines $(d=I .15 \mathrm{~mm})$ were included with both sets of data in the curve-fitting procedure because of the uncertainty in determining whether they should be included with the fine-grained data or the coarse-grained data. On all points, error bars representing $99 \%$ confidence limits on slope of secondary-creep curve (Krumbein and Graybill, $1965, p .230$ ) are smaller than dot. All creep data are plotted as uniaxial compressive strain-rates.

\section{Discussion}

\section{Interpretation of grain-size studies}

With metals, the dependence of secondary-creep rate on grain diameter at high temperatures has been investigated by a large number of researchers. Parker (1958) found that for copper at $400^{\circ} \mathrm{C}\left(0.5 T_{m}\right.$, where $T_{\mathrm{m}}$ is the melting temperature), the secondary-creep rate increases with increasing grain diameter. This was also found true at $0.6 T_{\mathrm{m}}$ by Feltham and Meakin (1959) who showed that secondary-creep rate $\dot{\epsilon}$ is proportional to the grain diameter $d$ squared. A similar observation was made for brass at $0.6 T_{\mathrm{m}}$ (Feltham and Copley, 196o). McKeown (1937), however, found that the creep rate for lead at $0.5 T_{\mathrm{m}}$ is proportional to $\mathrm{I} / d$ - that is, $\dot{\epsilon}$ decreases with increasing $d$. At temperatures near the melting point where stress-directed diffusion of vacancies may lead to viscous creep, a dependence of $\mathrm{I} / d^{2}$ has been 
found for copper (Pranatis and Pound, r 955). For tin at o.6 $T_{\mathrm{m}}$, Hanson (1939) found that $\dot{\epsilon}$ decreases to a minimum as $d$ increases and then increases as $d$ is further increased. Similar results were observed for Monel at various temperatures up to $0.8 T_{\mathrm{m}}$ (Shahinian and Lane, I953) and for austenitic steel at $0.55 T_{\mathrm{m}}$ (Garofalo and others, I964). The latter studies represent the most complete experiments showing the influence of average crystal size on creep rate. Other studies used a more limited range of crystal sizes and thus failed to detect the creep-rate minimum at intermediate crystal sizes.

\section{Grain-boundary strengthening}

For large crystal sizes ( $>_{\mathrm{I}} \mathrm{mm}$ ), the linear decrease in $\dot{\epsilon}$ with decreasing values of $d$ in Figure 2 has been observed for metals and is commonly referred to as grain-boundary strengthening (Armstrong, 1970). This strengthening effect, due to grain-size refinement, is usually demonstrated by performing tension or compression tests and showing that the yield or flow stress $\sigma$ depends on the average grain diameter $d$ according to the Hall-Petch relationship:

$$
\sigma=\sigma_{0}+k d^{-\frac{1}{2}}
$$

where $\sigma_{0}$ and $k$ are experimental constants. This relationship has been observed for coarse grained $(>2.00 \mathrm{~mm})$ columnar ice by Muguruma (1969).

The theory for understanding Equation (2) comes from consideration of dislocationcontrolled creep. Grain boundaries are obstacles to dislocation motion and resist penetration by moving dislocations (Armstrong, 1970). Hence, dislocations have a tendency to pile-up at crystal boundaries. These pile-ups act as stress concentrators and can cause plastic flow to start in a neighboring grain. The inverse square-root dependence on grain size in the HallPetch relationship is due to the fact that a dislocation pile-up that extends across one grain, produces a stress in an adjacent grain that is inversely proportional to the square root of the length $d$ of the pile-up (Petch, I953). Thus, short pile-ups produce lower internal stress concentrations, and consequently, a larger applied stress is necessary to cause flow. This implies that at a constant stress, coarse-grained materials are weaker and will thus deform more rapidly (have higher secondary-creep rates) than fine-grained materials.

The grain-size dependence of secondary-creep rate for coarse-grained metals at high temperatures has been shown by Sherby $(1962)$ to be:

$$
\dot{\epsilon}=s d^{2} D_{\mathbf{v}}\left(\frac{\sigma}{E}\right)^{n},
$$

where $s$ is a constant for high-temperature creep, $d$ is the average grain diameter, $D_{\mathrm{v}}$ is the coefficient for bulk diffusion, $\sigma$ is the applied stress, $E$ is the elastic modulus, and $n$ is an experimental constant. Diffusion is a thermal activation process which plays an important role in high-temperature creep. Hence, the diffusion term in Equation (3).

Equation (3) predicts that creep rate is proportional to the square of the average grain diameter. The slope of a least-squares line through the data for coarse-grained ice $(d>$ I.o $\mathrm{mm}$ ) in Figure 2 is $2.5^{\circ}$ (correlation coefficient $\left.=0.9 \mathrm{I}\right)$. Hence, creep rate is proportional to the 2.5 power of the average crystal size; a fair agreement with Sherby's model. As a further check for compatibility with the ice-compression tests and using appropriate values for ice at $-10^{\circ} \mathrm{C}\left\{D_{\mathrm{v}}=\mathrm{I} \times \mathrm{IO}^{-9} \mathrm{~mm}^{2} \mathrm{~s}^{-1}\right.$ (Glen, 1974, p. 44$), E \simeq 9.5 \times 10^{3} \mathrm{MN} \mathrm{m}^{-2}$ (Hobbs, I974), $s \approx \mathrm{I} \times \mathrm{IO}^{14} \mathrm{~mm}^{-4}$ (following Sherby, $\mathrm{I} 962$ ), $n=3$, and $\left.\sigma=0.56 \mathrm{MN} \mathrm{m}^{-2}\right\}$, Equation (3) has been plotted on Figure 3. From this figure it can be seen that in spite of the uncertainty in the constant, $s$, Equation (3) fits the experimental data reasonably well.

Glen (1968) has shown that the motion of dislocations through the ice lattice is opposed by the disorder of hydrogen atoms on the $\mathrm{O}-\mathrm{H}-\mathrm{O}$ bonds in ice. If protons $\left(\mathrm{H}^{+}\right)$cannot rearrange ahead of a dislocation, Bjerrum-point defects (D and $\mathrm{L}$ defects) are formed. The 
creation of these defects requires such energy that slip is only possible at stresses of about one-tenth the shear modulus. Thus deformation at any lower stress is possible only if the generation of these defects can be avoided by the ability of Bjerrum defects already present in the lattice due to thermal activation, to reorient the bonds ahead of dislocations (Glen, I968). The rate at which these bonds can be reoriented, therefore, limits the velocity of dislocations (Whitworth and others, 1976) and suggests that the rate-controlling mechanism for creep of ice, may be the mobility of dislocations in their glide planes rather than dislocation climb (Barnes and others, I97 I). This is in contrast to the behavior of pure metals where the ratecontrolling process for intergranular creep is dislocation climb (Sherby, I962).

At the present time, the Glen model has not been sufficiently quantified for a grain-size term to be apparent (Perez and others, 1975; Whitworth and others, 1976; Frost and others, 1976). However, the grain-size dependence of the Glen model should be similar to the Sherby model because in both cases the stress concentration in a slip plane should be a function of a grain-size dependent pile-up. Therefore, the relationships presented in Figure 3 appear to be compatible with the Glen model.

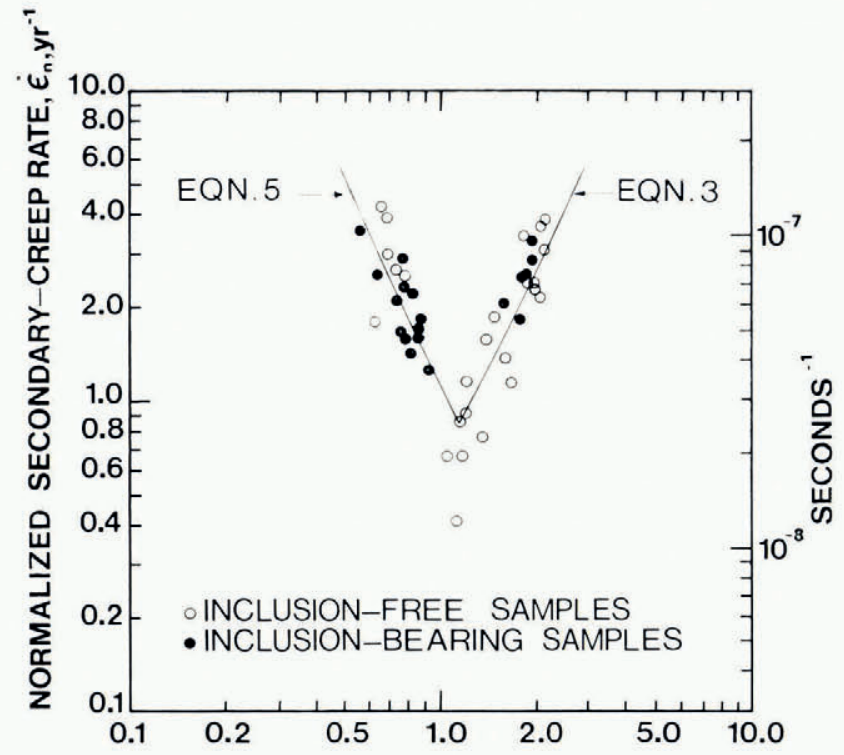

AVERAGE GRAIN DIAMETER, $d, \mathrm{~mm}$

Fig. 3. Normalized secondary-creep rate versus average grain diameter for both inclusion-bearing and inclusion-free samples. All creep data are plotted as uniaxial compressive strain-rates.

\section{Grain-size weakening}

For ice-crystal sizes less than $\mathrm{I}$ mm in diameter, the increase in creep rate with decreasing average crystal size (Fig. 2) has also been observed with fine-grain metals and is generally referred to as grain-size weakening (Armstrong, 1970). At low stresses or high temperatures a material can be weakened by two major grain-boundary processes: (I) grain-boundary sliding or shearing which occurs to an increasing degree as the grain size decreases; (2) grainboundary enhancement of diffusion-controlled deformation mechanisms. Grain boundaries can contribute to increasing diffusion by offering short-circuiting routes for mass transport and by acting as sources or sinks for point defects — namely vacancies and interstitials (Coble, I963). 
Nabarro (1948) and Herring (I950) have formulated models which describe diffusioncontrolled deformation of polycrystalline masses. The Nabarro-Herring model predicts that appreciable creep rates can be produced in very fine-grained material by a diffusional mass transport of atoms from one grain boundary to another. The model also predicts that the creep rate will vary directly with the stress and inversely with the square of the average grain diameter, thus

$$
\dot{\epsilon}=\left(\alpha D_{\mathrm{v}} / d^{2}\right)(\sigma \Omega / k T) .
$$

In this equation $\alpha$ is a constant, $\Omega$ is the atomic volume, $k$ is Boltzmann's constant, $T$ is the absolute temperature, and the other symbols are as defined earlier.

The dual roles of bulk diffusion and grain-boundary diffusion in high-temperature creep have been discussed by Raj and Ashby (I97I) and Gittus (I975) who modified the NabarroHerring creep equation to

$$
\dot{\epsilon}=\alpha \frac{\sigma \Omega}{k T d^{2}} D_{\mathrm{v}}\left\{\mathrm{I}+\frac{\pi \delta}{d} \frac{D_{\mathrm{B}}}{D_{\mathrm{v}}}\right\},
$$

where $\delta$ is the width of a grain boundary, and $D_{\mathrm{B}}$ is the coefficient for grain-boundary diffusion. From this equation it may be noted that at constant stress and temperature, if $\pi \delta D_{\mathrm{B}} / d D_{\mathrm{v}}$ is much less than $\mathrm{I}$, the creep rate is proportional to $\mathrm{I} / d^{2}$. For ice at $-10^{\circ} \mathrm{C}$, $D_{\mathrm{v}} \approx \mathrm{I} \times \mathrm{IO}^{-9} \mathrm{~mm}^{2} \mathrm{~s}^{-\mathrm{I}}$ (Glen, $\mathrm{I} 974$, p. 44), $D_{\mathrm{B}} \approx \mathrm{I} \times \mathrm{IO}^{-5} \mathrm{~mm}^{2} \mathrm{~s}^{-\mathrm{I}}$ (Glen, $\left.\mathrm{I} 974, \mathrm{p} .44\right)$, and $\delta=9 \times 10^{-7} \mathrm{~mm}$ (paper by D. J. Goodman, H. J. Frost, and M. F. Ashby on the effect of impurities on the creep of ice Ih, in preparation). Using $d=0.68 \mathrm{~mm}$ (Sample I8, Table I) it follows that $\pi \delta D_{\mathrm{B}} / d D_{\mathrm{v}} \approx 0.042 \ll \mathrm{I}$.

For the present study, the slope of a least-squares line through the data for fine-grained ice on the left side of Figure 2 is -2.35 (correlation coefficient $=0.88$ ), an acceptable agreement with the Nabarro-Herring model. As a further test for the applicability of this model, Equation (5) has been fitted to the data for fine-grained ice in Figure 3 using a value of $2.8 \times \mathrm{IO}^{3}$ for $\alpha$ and values appropriate for ice at $-\mathrm{IO}^{\circ} \mathrm{C}$ for the other terms. This rather high value of $\alpha$ may be reasonable as values of this constant ranging over three orders of magnitude have been reported for fine-grained metals (Weertman, i968; Ashby and Verrall, r973).

There is some evidence for diffusional creep from previous studies. Although grain-size data are in some cases lacking and several tests were conducted at low stresses, Jellinek and Brill (r 956), Butkovitch and Landauer (1960), Mellor and Smith (r966), Bromer and Kingery (1968), and Colbeck and Evans (1973) all found a first-power stress dependence characteristic of such creep (Equation (5)) and Bromer and Kingery (1968) found that creep rate varied with the inverse square of the grain diameter. It should be noted here that Weertman (I973) and Hobbs (1974) suggest that the first-power creep observed by these investigators may be suspect since the total strains were so small in their experiments that true secondary creep may not have been established. However, Goodman (unpublished) has shown, through deformation mapping, that linear flow can be expected for ice samples with average crystal sizes of less than $\mathrm{I} \mathrm{mm}$ and for stresses of at least $0 . \mathrm{I} \mathrm{MN} \mathrm{m}^{-2}$ ( $\mathrm{I}$ bar). Thus, at least tentatively, it appears that for fine-grained ice $(d<1.0 \mathrm{~mm})$ at temperatures of about $-\mathrm{Io}^{\circ} \mathrm{C}$, Equation (5) is valid and the creep rate may be controlled by diffusional processes.

\section{Effect of inclusions on ice-crystal size}

The freezing process can be separated into two parts, the initial nucleation of crystals and the subsequent growth of these nuclei by the accretion of molecules from the melt. Tiller (1965) has shown that spontaneous crystal growth, which must be accompanied by a decrease in free energy, occurs only below the melting point and only for relatively large clusters of molecules. Furthermore, once these embryos have formed they will continue to grow at the expense of the melt unless their growth is inhibited by collisions with other nuclei or foreign 
particles. The samples tested in this study were prepared using a porous mixture of finepowdered ice and sand. Hence, following Tiller, it is assumed that the fine-ice particles served as sites of crystal nucleation.

During solidification, the free energy of the liquid-solid interface is generally less than that of an intercrystalline grain boundary (Smith, I948). Thus, as long as there is even a trace of liquid left, surface tension will insure that all surfaces of a crystal are wet. As fast as liquid freezes, more will be brought in by capillary action (Smith, 1948). Therefore, even though two growing crystals meet each other and consume all of the liquid between them, growth will continue by capillary feeding to the interface which eventually becomes a grain boundary. One grain will not cohere to another even under light pressure as long as liquid is present.

The interface energy between two different solid phases, as for example between the matrix material and an inclusion, is generally more than half the energy associated with the grain boundary of either phase (Smith, I948, p. 34). Hence, during grain growth, secondphase particles tend to remain along crystal boundaries due to the more stable energy configuration of this location. The arguments of Smith (1948) are supported by observations made on ice during this study. Point counts of approximately $\mathrm{I}$ ooo sand grains in thin sections of inclusion-bearing ice made for laboratory experiments as well as thin sections of glacier ice from the Barnes Ice Cap, N.W.T., Canada, showed that $87 \%$ of the particles were located on crystal boundaries.

Inclusions play and important role in determining the final grain size achieved during crystal growth. Because an inclusion will tend to become attached to a grain boundary, rather than be included within the crystal, a rigid and insoluble inclusion will effectively anchor the boundary locally (Van Vlack, 1965). If a moving crystal boundary encounters such a particle, it will locally cling to it causing an indentation in the surface. Before a boundary can move beyond a dispersed particle, the total boundary area must be increased and the radius of curvature reversed locally. If a sufficient number of inclusions is present, grain boundaries can be effectively pinned and crystal growth is thus limited. C. Zener (see Smith, 1948) has treated this concept semi-quantitatively in the following manner.

The driving force for grain growth is provided by surface tension, $\gamma$, and is given by the following relation:

$$
F_{\mathrm{D}} \approx \gamma / R,
$$

where $R$ is the net radius of curvature of the grain boundary. The restraining force for each inclusion of radius $r$ is

$$
F_{\mathrm{R}}=2 \pi r \sin \omega \cos \omega
$$

where $\omega$ is the angle between the average surface of the grain boundary and the surface at the point where it joins the inclusion. For a maximum restraining force, $\omega$ is $45^{\circ}$ and $\sin \omega \cos \omega$ equals $\frac{1}{2}$.

The total restraining force action on the boundary is

$$
F=n_{\mathrm{s}} \pi r \gamma,
$$

where $n_{\mathrm{s}}$ is the number of inclusions per unit area of grain boundary. Equating this to the driving force given by Equation (6), for equilibrium it is found that

$$
\pi n_{\mathrm{s}} r R=\mathrm{I} .
$$

The surface density $n_{\mathrm{s}}$ is approximately

$$
n_{\mathrm{s}}=n_{\mathrm{v}} r
$$

where $n_{\mathrm{v}}$ is the number of particles per unit volume or

$$
n_{\mathbf{v}}=\frac{f}{\frac{4}{3} \pi r^{3}},
$$


where $f$ is the fraction of the total volume occupied by inclusions. Combining Equations (9), (IO), and (I I), we have

$$
R_{\max }=\frac{4^{r}}{3 f}
$$

Recent experimental and more detailed theoretical analyses (Ashby and others, I969) have established that Equation (12) is essentially correct.

For the inclusion-bearing ice samples tested during this study, Equation (12) predicts grain sizes much larger, generally by more than a factor of four, than were actually observed. This can perhaps be explained because Equation (12) assumes a homogeneous distribution of inhibiting particles (C. Zener, see Smith, 1948) which probably did not exist in the samples tested. The very nature of sample preparation - particles of ice, which act as nucleation sites, surrounded by particles of sand-undoubtedly results in local regions of high inclusion density around centers of crystal growth (ice particles). Subsequently, during crystallization of the ice samples, grain boundaries become pinned in these regions of high density where there is a locally high value of $f$ (Equation (12)). It is also possible that during freezing there were so many competing nucleation sites that the ice crystals were prevented from growing to maximum size. Nevertheless, the present study indicates that, to a first approximation, one can anticipate a definite relationship between the fraction of the total volume occupied by inclusions and the ultimate ice-crystal size achieved upon crystallization (Fig. 4).

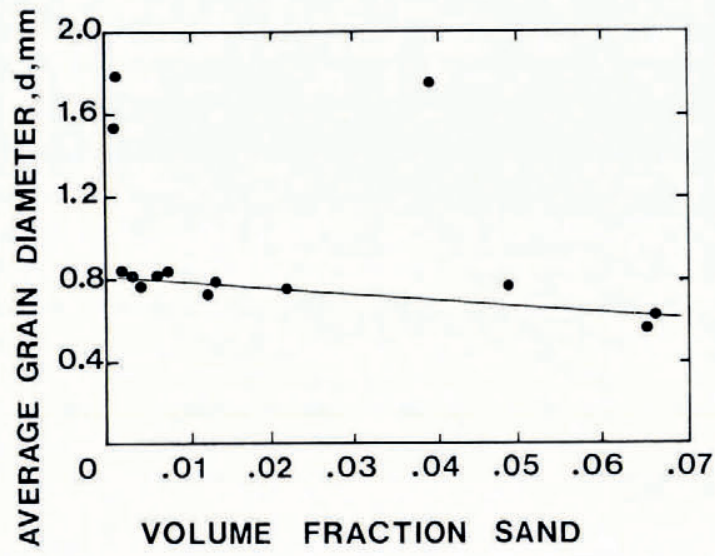

Fig. 4. Relationship of volume-fraction inclusions to the ultimate grain size produced upon crystallization.

\section{Effect of inclusions on dislocation movement}

The possibility remains that the presence of inclusions may influence dislocation movement. In order to discuss this possibility it is necessary to evaluate the average inclusion spacing $\lambda$ in terms of the average inclusion size $a$ and the volume-fraction inclusions $f$. From Equation (I I) the total number of inclusions per unit volume of sample $n_{\mathrm{v}}$ is

$$
n_{\mathrm{v}}=\frac{f}{\frac{4}{3} \pi(a / 2)^{3}} .
$$

Because most inclusions are located on grain boundaries, $n_{\mathbf{v}}$ can be modified to represent the total number of particles per unit boundary area. If a simple model of cubic crystals of dimension $d$ is used, $n_{\mathrm{v}}$ is equal to the number of particles on one boundary $(d / \lambda)$ times half 
the number of boundaries per grain (the half is the result of each particle being shared by two boundaries), divided by the volume of a cubic crystal, $d^{3}$. Thus

$$
n_{\mathrm{v}}=\frac{3 d^{2} / \lambda^{2}}{d^{3}}=\frac{f}{{ }_{3}^{4} \pi(a / 2)^{3}},
$$

and solving for the particle spacing

$$
\lambda^{2}=\frac{\pi a^{3}}{2 d f} .
$$

In the present study, the inclusion size was o. $1 \mathrm{~mm}$, approximately an order of magnitude smaller than the average ice-crystal size of most of the samples tested. From Equation ( I5), the average particle spacing for Sample $4(f=0.066$, Table II $)$ was about $0.2 \mathrm{~mm}$. Because this sample contained the highest volume fraction of inclusions, the particle spacing in all of the other inclusion-bearing samples was greater. Due to this large particle spacing, coupled with the location of most inclusions on grain boundaries, it is not believed that these particles were effective obstacles to dislocation motion; when rigid inclusions are dispersed throughout the matrix of most metals, interference with dislocation movement is not achieved until the particle spacing is, in general, two to three orders of magnitude smaller than that of the present study (Martin, ig68).

\section{Conclusions}

I. The creep rate of polycrystalline ice at high temperatures and moderate stresses with a random orientation of $c$-axes, is extremely sensitive to variations in ice-crystal size. Doubling or halving the average crystal size from about $\mathrm{I} \mathrm{mm}$ results in roughly a factor of four increase in secondary-creep rate.

(a) For coarse-grained ice (average diameter greater than about r.o $\mathrm{mm}$ ), it appears that creep is dominated by internal dislocation movement with creep rate controlled by the mobility of dislocations in their glide planes. Crystal boundaries are obstacles to dislocation motion; reducing the crystal size thus results in a reduction in secondarycreep rate in proportion to about the square of the average grain diameter.

(b) For fine-grained ice (average diameter less than about $1.0 \mathrm{~mm}$ ), creep appears to be dominated by diffusional processes. Reduction of ice-crystal size results in an increase in secondary creep-rate in proportion to about the inverse-square of the average grain diameter.

(c) It appears that for fine-grained ice, an inversion between dislocation-controlled creep and diffusion-controlled creep occurs at about $\mathrm{r} .0 \mathrm{~mm}$ and that this is optimum grain size for creep resistance. Increasing or decreasing the average crystal size from this critical value will result in an increase in secondary-creep rate.

2. During freezing, the presence of inclusions in low concentrations inhibit crystal growth; an increase in the volume-fraction of inclusions results in a reduction in average ice-crystal size.

3. Due to the large particle spacing in the inclusion-bearing samples and the fact that most inclusions are located on crystal boundaries, it is not believed that these particles were effective obstacles to dislocation motion.

\section{AcKnowledgements}

This study was supported by National Science Foundation grants GA-r93 ro and GA42728 , the Glaciology Division, Department of the Environment, Canada, and the University of Minnesota Graduate School. I am particularly grateful to R. LeB. Hooke for arousing my interest in the rheology of ice, for many perceptive discussions on the subject, for use of a computer program which formed the basis for the creep-rate calculations, and for critically 
reading the manuscript. I am also indebted to P. J. Hudleston and W. W. Gerberich for many valuable discussions and the suggestions they offered during the various phases of this study.

The writer further expresses his gratitude to $\mathrm{R}$. Plunkett for the valuable suggestions he made in the early phases of this study; to M. T. Kauper for his help in setting up the experimental apparatus; to B. R. Koci for his technical assistance and advice, and to D. I. Norman, K. Barr, G. Braun, and T. Holst, for their aid and advice in various phases of the study which were most helpful. The comments of an anonymous reviewer resulted in a number of improvements in the paper.

\section{REFERENCES}

Armstrong, R. W. I970. Strength properties of ultrafine grain metals. (In Burke, J. J., and Weiss, V., ed. Ultrafinegrain metals. Syracuse, N.Y., Syracuse University Press, p. I-26.)

Ashby, M. F., and Verrall, R. A. 1973. Diffusion-accommodated flow and superplasticity. Acta Metallurgica, Vol. 21, No. 2, p. 149-63.

Ashby, M. F., and others. 1969. The interaction of crystal boundaries with second-phase particles, by M. F. Ashby, J. Harper and J. Lewis. Transactions of the Metallurgical Society of the A.I.M.E., Vol. 245, No. 2, p. 413-20.

Baker, R. W. Unpublished. The influence of ice-crystal size and dispersed-solid inclusions on the creep of polycrystalline ice. [Ph.D. thesis, University of Minnesota, Minneapolis, Minnesota, 1977.]

Barnes, P., and others. 1971. Friction and creep of polycrystalline ice, by P. Barnes, D. Tabor and J. C. F. Walker. Proceedings of the Royal Society of London, Ser. A, Vol. 324, No. 1557, p. 127-55.

Bromer, D. J., and Kingery, W. D. 1968. Flow of polycrystalline ice at low stresses and small strains. Fournal of Applied Physics, Vol. 39, No. 3, p. 1688-91.

Butkovitch, T. R., and Landauer, J. K. 1958 . The flow law for ice. Union Géodésique et Géophysique Internationale. Association Internationale d'Hydrologie Scientifique. Symposium de Chamonix, 16-24 sept. 1958, p. 318-27. (Publication No. 47 de l'Association Internationale d'Hydrologie Scientifique.)

Butkovitch, T. R., and Landauer, J. K. I960. Creep of ice at low stresses. U.S. Snow, Ice and Permafrost Research Establishment. Research Report 72.

Coble, R. L. 1963. A model for boundary diffusion controlled creep in polycrystalline materials. Fournal of Applied Physics, Vol. 34, No. 6, p. 1679-82.

Colbeck, S. C., and Evans, R. J. 1973. A flow law for temperate glacier ice. Journal of Glaciology, Vol. 12, No. 64, p. $7 \mathrm{I}-86$.

Feltham, P., and Copley, G. J. 1960. Creep in face-centered metals and solid inclusions with special references to $\alpha$-brasses. Philosophical Magazine, Eighth Ser., Vol. 5, No. 55, p. 649-67.

Feltham, P., and Meakin, J. D. 1959. Creep in face-centered cubic metals with special reference to copper. Acta Metallurgica, Vol. 7, No. 9, p. 614-26.

Frost, H. J., and others. 1976. Kink velocities on dislocations in ice. A comment on the Whitworth, Paren and Glen model, by H. J. Frost, D. J. Goodman and M. F. Ashby. Philosophical Magazine, Eighth Ser., Vol. 33, No. 6 , p. $95^{\mathrm{I}-6 \mathrm{I}}$.

Garofalo, F., and others. I964. Effect of grain size on the creep behavior of an austenitic iron-base alloy, by F. Garofalo, W. F. Domis and F. von Gemmingen. Transactions of the Metallurgical Society of the A.I.M.E., Vol. 230, No. 6, p. 1460-67.

Gittus, J. 1975. Creep, viscoelasticity and creep fracture in solids. New York, John Wiley and Sons, Inc.

Glen, J. W. 1955. The creep of polycrystalline ice. Proceedings of the Royal Society of London, Ser. A, Vol. 228, No. 1175 , p. 519-38.

Glen, J. W. 1968. The effect of hydrogen disorder on dislocation movement and plastic deformation of ice. Physik der kondensierten Materie, Bd. 7, Ht. I, p. 43-51.

Glen, J. W. r974. Physics of ice. U.S. Cold Regions Research and Engineering Laboratory. Cold regions science and engineering. Hanover, N.H., Pt. II, Sect. C2a.

Gold, L. W. 1958. Some observations on the dependence of strain on stress for ice. Canadian Journal of Physics, Vol. 36 , No. 1o, p. 1265-75.

Goodman, D. J. Unpublished. Creep and fracture of ice and surface strain measurements on glaciers and sea ice. [Ph.D. thesis, University of Cambridge, 1977.]

Hall, E. O. 195I. The deformation and ageing of mild steels: III. Discussion of results. Proceedings of the Physical Society, Vol. B64, Pt. 8, p. 747-53.

Hanson, D. 1939. The creep of metals. Transactions of the Metallurgical Society of the A.I.M.E., Vol. 133, p. I5-57.

Herring, C. 1950. Diffusional viscosity of a polycrystalline solid. Fournal of Applied Phyiscs, Vol. 21, No. 5, p. $437-45$.

Hobbs, P. V. 1974. Ice physics. Oxford, Clarendon Press.

Hooke, R. L., and others. I972. Creep of ice containing dispersed fine sand, by R. L. Hooke, B. B. Dahlin and M. T. Kauper. Fournal of Glaciology, Vol. i i, No. 63 , p. $327-36$.

Jellinek, H. H. G., and Brill, R. 1956. Viscoelastic properties of ice. Journal of Applied Physics, Vol. 27, No. 10, p. $1198-1209$.

Kellerhals, R., and others. 1975. On grain size from thin sections, by R. Kellerhals, J. Shaw and V. K. Arora. Journal of Geology, Vol. 83, No. I, p. 79-96. 
Krumbein, W. C. 1935. Thin section mechanical analysis of indurated sediments. Fournal of Geology, Vol. 43, No. 5 , p. $482-96$.

Krumbein, W. C., and Graybill, F. A. 1965. An introduction to statistical models in geology. New York, McGraw-Hill Book Co., Inc.

McKeown, J. 1937. Creep of lead and lead alloys. Part $\mathrm{I}$-creep of virgin lead. Fournal of the Institute of Metals, Vol. 6o, No. I, p. $20 \mathrm{I}-28$.

Martin, J. W. 1968. Precipitation hardening. New York, Pergamon Press.

Mellor, M., and Smith, J. H. 1966. Creep of snow and ice. U.S. Cold Regions Research and Engineering Laboratory. Research Report 220.

Mellor, M., and Testa, R. 1969. Effect of temperature on the creep of ice. Journal of Glaciology, Vol. 8, No. 52, p. I 3 I -45 .

Muguruma, J. I969. Effects of surface condition on the mechanical properties of ice crystals. British Fournal of Applied Physics (Journal of Physics, D), Ser. 2, Vol. 2, No. 1 1, p. $1517-25$.

Nabarro, F. R. N. 1948. Deformation of crystals by the motion of single ions. (In Report of a conference on strength of solids held at the H. H. Wills Physical Laboratory, University of Bristol, on 7-9 July 1947. London, Physical Society of London, p. 75-9o.)

Parameswaran, V. R. I975. Serrated yielding in ice single crystals. Scripta Metallurgica, Vol. 9, No. 9, p. 93 I-34.

Parker, E. R. 1958. Modern concepts of flow and fracture. Transactions of American Society of Metals, Vol. 50, p. $5^{2-104}$.

Perez, J., and others. 1975. Comportement dynamique des dislocations dans la glace, par J. Perez, J. Tatibouët, R. Vassoille et P.-F. Gobin. Philosophical Magazine, Eighth Ser., Vol. 31, No. 5, p. 985-99.

Petch, N. J. 1953. The cleavage strength of polycrystals. Fournal of the Iron and Steel Institute, Vol. I 74, Pt. I, p. $25-28$.

Pranatis, A. L., and Pound, G. M. 1955. Viscous flow of copper at high temperatures. Transactions of the Metallurgical Society of the A.I.M.E., Vol. 203, No. 5, p. 664-68.

Raj, R., and Ashby, M. F. I97ı. On grain boundary sliding and diffusional creep. Metallurgical Transactions, Vol. 2, No. 4, p. I I I $3-27$.

Shahinian, P., and Lane, J. R. 1953. Influence of grain size on high temperature properties of Monel. Transactions of American Society of Metals, Vol. 45, p. 1 77-99.

Sherby, O. D. 1962. Factors affecting the high temperature strength of polycrystalline solids. Acta Metallurgica, Vol. 10, No. 2, p. 135-47.

Smith, C. S. 1948. Grains, phases, and interphases: an interpretation of microstructure. Transactions of the Metallurgical Society of the A.I.M.E., Vol. I 75, p. 15-51.

Tiller, W. A. 1965. Solidification. (In Cahn, R. W., ed. Physical metallurgy. New York, John Wiley and Sons, Inc., p. $385-441$.)

Van Vlack, L. H. ${ }^{1965}$. Microstructures. (In Cahn, R. W., ed. Physical metallurgy. New York, John Wiley and Sons, Inc., p. 589-614.)

Weertman, J. 1968. Dislocation climb theory of steady-state creep. Transactions of American Society of Metals, Vol. 6r, p. $68 \mathrm{I}-94$.

Weertman, J. r 969 . The stress dependence of the secondary creep rate at low stresses. Fournal of Glaciology, Vol. 8, No. 54, p. 494-95. [Letter.]

Weertman, J. I973. Creep of ice. (In Whalley, E., and others, ed. Physics and chemistry of ice: papers presented at the Symposium on the Physics and Chemistry of Ice, held in Ottawa, Canada, I4-18 August 1972. Edited by E. Whalley, $S$. F. Fones, L. W. Gold. Ottawa, Royal Society of Canada, p. 320-37.)

Whitworth, R. W., and others. 1976. The velocity of dislocations in ice-a theory based on proton disorder, by R. W. Whitworth, J. G. Paren and J. W. Glen. Philosophical Magazine, Eighth Ser., Vol. 33, No. 3, p. 409-26.

\section{DISGUSSION}

D. J. Goodman: I would like to comment on this paper by showing three deformation maps for grain sizes of o. I, I.o, and $6.3 \mathrm{~mm}$ (Figs DI-3). The maps have been constructed using the equation you quoted for diffusional creep with diffusion constants from the diffusion data of Ramseier ( 1967 ), and a semi-empirical constitutive equation for proton-rearrangementcontrolled glide which has been fitted to the available polycrystalline creep data (Goodman, unpublished). One can readily see that if ice specimens could be made with grain sizes well below I mm, their linear flow corresponding to Nabarro-Herring diffusional creep could be observed at measurable strain-rates $\left(c\right.$. $\mathrm{IO}^{-8}$ to $\left.\mathrm{IO}^{-7} \mathrm{~s}^{-1}\right)$, at stresses of the order of $0 . \mathrm{I} \mathrm{MNm}^{-2}$. At these stresses the time for transient creep (due to its dislocation density changes) to disappear is of the order of hours. 


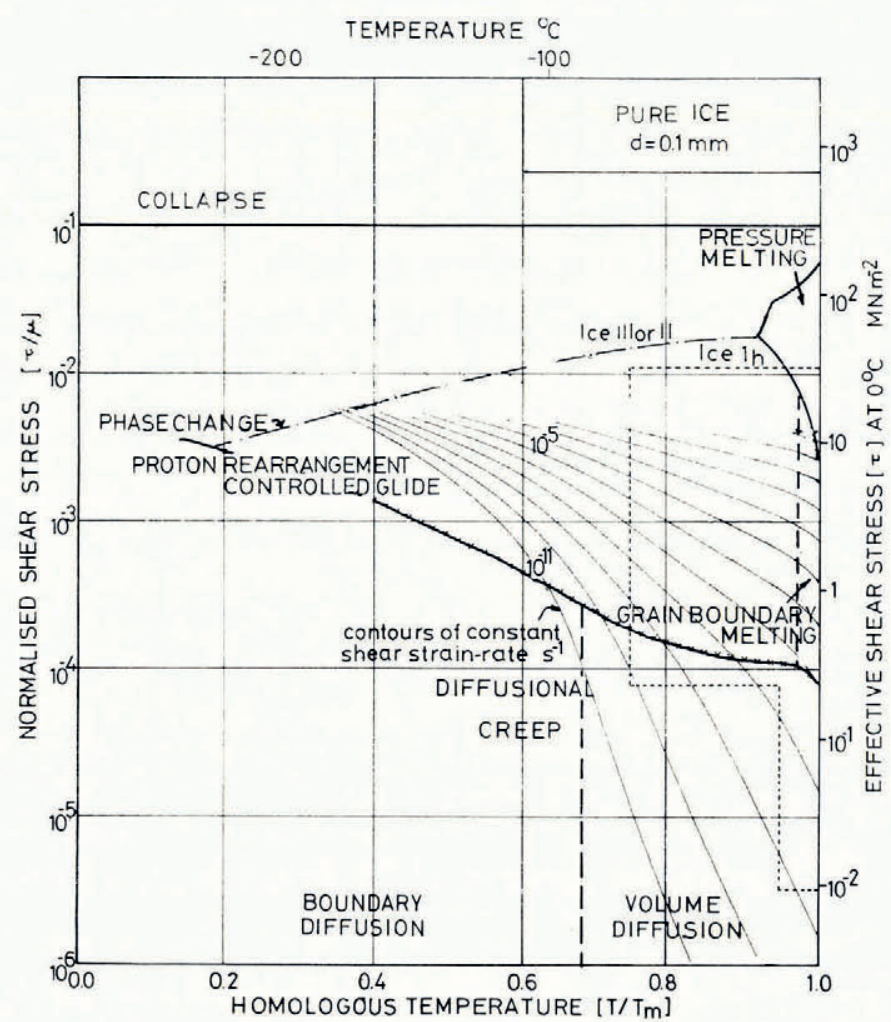

Fig. DI. Deformation-mechanism map for polycrystalline ice of $0.1 \mathrm{~mm}$ grain size.

R. W. BAKER: Your deformation maps are very interesting. I am pleased to see that the effect of ice-crystal size on creep predicted by your model is quite compatible with the data I have presented here.

P. Duval: You have discussed two deformation processes, the diffusion-controlled creep for small grain size and the dislocation-controlled creep for crystal sizes greater than about $7.0 \mathrm{~mm}$. Have you verified that the transient creep is small when the diffusion-controlled creep occurs, compared to the transient creep when the dislocation creep occurs? Or, another way of asking the same question, have you found a variation of transient creep with crystal size?

BAKER: In order to compare my data with results of previous creep studies on ice (both laboratory tests and field measurements on glacier flow), I was primarily interested in the secondary or steady-state creep regime. Consequently, I have not made any careful study of the creep data obtained during the transient-creep phase. As I recall, the very fine-grained samples $(d<\mathrm{I} .0 \mathrm{~mm})$ reached what appeared to be steady-state creep more rapidly than the coarse-grained samples. However, as to how much smaller the transient-creep phase was, and whether there is a correlation between transient creep and crystal size, I cannot say at this time.

W. B. KAMB: Since the diffusion-creep and dislocation-creep strain-rates are additive, the creep-rate minimum that should be found near the grain size where the two mechanisms contribute equally should be broad (parabolic) rather than a sharp $\mathrm{V}$ as your data suggest. 


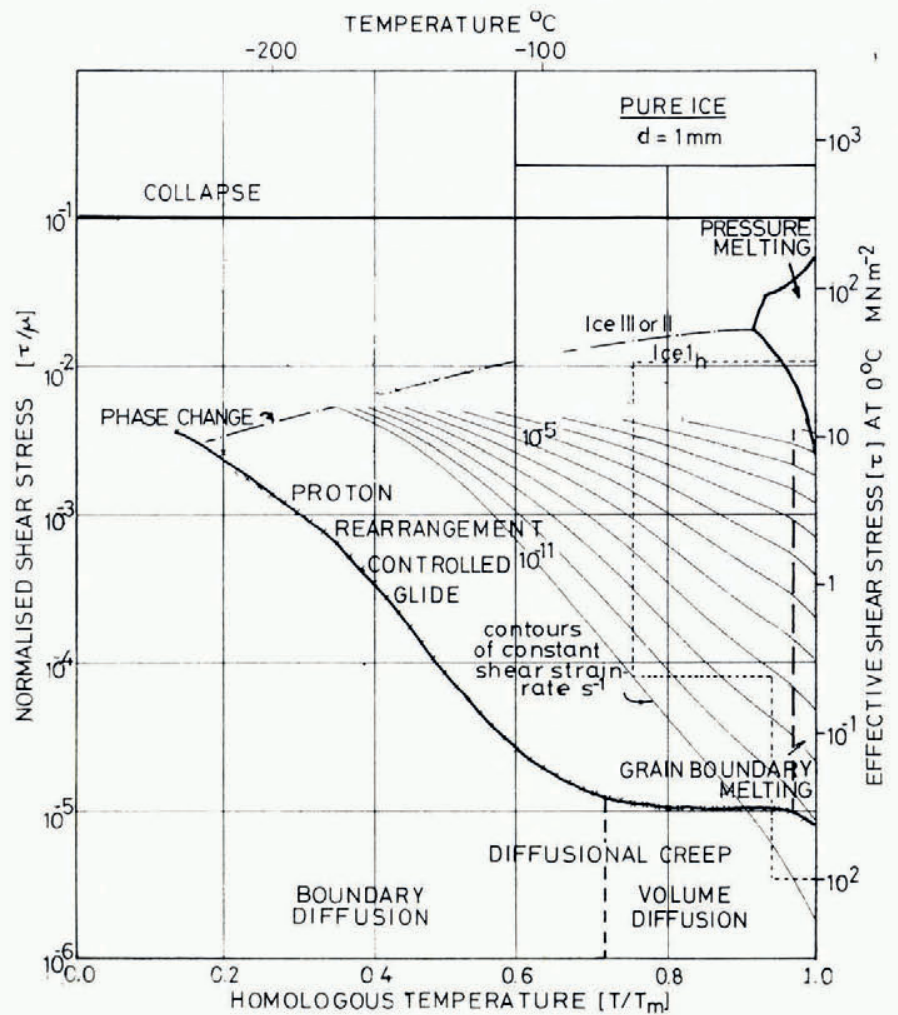

Fig. D2. Deformation-mechanism map for polycrystalline ice of I $\mathrm{mm}$ grain size.

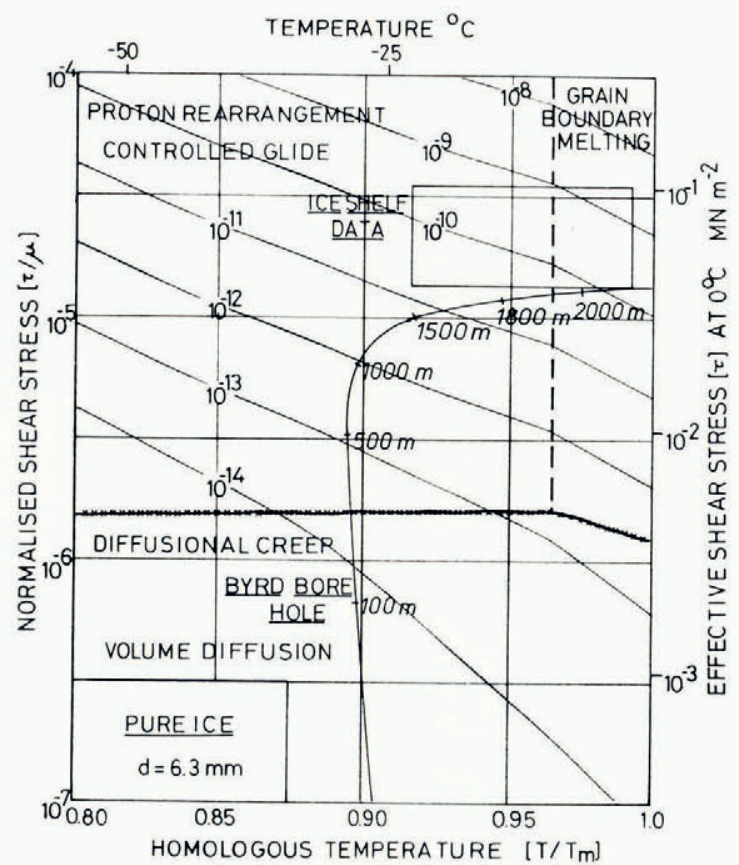

Fig. D3. Part of the deformation-mechanism map for polycrystalline ice of $6.3 \mathrm{~mm}$ grain size expanded to show the creep mechanisms in the stress/temperature regime of the "Byrd" bore hole and the ice-shelf data quoted by Thomas (I973). Lines plotted are contours of constant shear strain-rate in $\mathrm{s}^{-1}$. 
BAKER: I agree completely. The two creep mechanisms should be additive at the critical grain size. Some of the sharpness of the $V$ shape of the curves I presented can be explained by the scale at which the data were plotted. Even a parabola will look V-like if the scale is not sufficiently expanded. However, this does not explain the relatively large scatter of creep rates I found at about $1.0 \mathrm{~mm}$. Perhaps the nature of the transition between dislocation-controlled and diffusion-controlled creep is more complex than the models presented here indicate. Clearly this question deserves further careful study.

\section{REFERENGES}

Goodman, D. J. Unpublished. Creep and fracture of ice and surface strain measurements on glaciers and sea ice. [Ph.D. thesis, University of Cambridge, 1977.].

Ramseier, R. O. I967. Self-diffusion of tritium in natural and synthetic ice monocrystals. Fournal of Applied Physics, Vol. 38, No. 6, p. 2553-56.

Thomas, R. H. I 973 . The dynamics of the Brunt Ice Shelf, Coats Land, Antarctica. British Antarctic Survey. Scientific Reports, No. 79 . 